\title{
Can cerebral microbleeds cause an acute stroke syndrome?
}

\author{
James T.H. Teo, PhD, MRCP \\ Hawraman Ramadan, MRCP \\ Simone M. Gregoire, MD \\ Sana Mufti, MRCP \\ Gideon Lipman, MRCP \\ H. Rolf Jäger, FRCR \\ Nicholas Losseff, PhD, FRCP \\ David Werring, PhD, FRCP
}

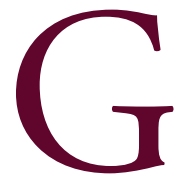

RE T2* MRI sequences are sensitive to tiny areas of previous bleeding (termed cerebral microbleeds $[\mathrm{CMBs}])^{1}$ due to the paramagnetic effects of blood degradation products including oxyhemoglobin and hemosiderin. CMBs are common and may be a prognostic marker of recurrent intracerebral hemorrhage, ${ }^{2}$ including antithrombotic related hemorrhage. ${ }^{3}$

Studies suggest that the chronic accumulation of CMBs may have an effect on anatomically distributed cerebral functions including cognition. ${ }^{4}$ As microbleeds cause focal damage to the brain tissue, ${ }^{5}$ acutely developing microbleeds might be expected to cause focal symptoms. We report 2 cases of acute focal neurologic symptoms and clinical signs that in each case appeared to be due to a CMB.

\section{Case 1}

A 69-year-old right-handed man with known hypertension awoke feeling dizzy and unsteady ("as if the room was spinning around him") and had numbness around his mouth and on his right cheek. When examined 2.5 hours later, his systolic blood pressure was $>200 \mathrm{~mm} \mathrm{Hg}$ and he had a right VII lower motor neuron palsy, gait ataxia, and gaze-evoked nystagmus on right gaze.

An urgent CT head and CT angiogram showed no focal abnormality (figure e-1). MRI using a Siemens 1.5 Tesla scanner was performed on the same day. GRE T2*-weighted sequences showed a CMB centered on the right side of the base of the pons close to the root entry zone of the VII/VIII nerves (figure 1A). There were no areas of restricted diffusion to suggest acute ischemia. After 24 hours, the patient made a full recovery. Follow-up MRI at 5 months confirmed that there was no underlying vascular malformation. The lesion was still present, although somewhat fainter, likely due to technical factors (figure e-2).

\section{Case 2}

A 78-year-old right-handed man presented with a sudden onset of paraesthesia over the left upper limb and left cheek. He had type II diabetes mellitus and hypertension. On assessment

National Hospital for Neurology and Neurosurgery (JTT, HR, SMG, GL, SM, HRJ, NL, DJW), Queen Square, London, UK; UCL Institute of Neurology (JTT, SMG, HRJ, DJW), Queen Square, London, UK.

Correspondence to: jthteo@gmail.com 


\section{Figure 1 Brain MRI}
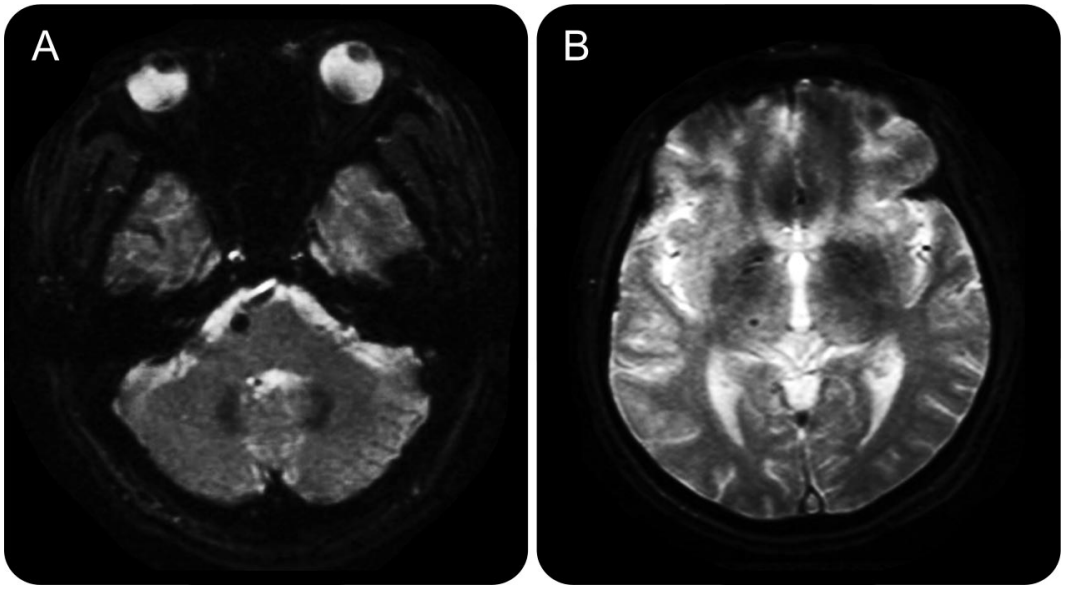

(A) MRI-brain gradient echo (GRE) axial T2* sequence showing a round 6-mm well-circumscribed hypointense lesion in the right pons in case 1. (B) MRI-brain GRE axial T2* sequence showing a 2-mm solitary brain microbleed in the ventral posterior nucleus of the right thalamus in case 2 .

the same day, he was hypertensive (blood pressure [BP] 210/92 $\mathrm{mm} \mathrm{Hg}$ ) and had reduced cold and pain sensation in the left maxillary and mandibular territory of the left $\mathrm{V}$ cranial nerve and the lateral aspect of the left forearm. MRI and magnetic resonance angiography carried out on the same day revealed a single focus of susceptibility artifact within the right inferolateral thalamus, consistent with a CMB (figure 1B). No other CMBs were seen elsewhere in the cerebral hemispheres or brainstem (figure e-3). His BP gradually and spontaneously reduced to $133 / 63 \mathrm{~mm} \mathrm{Hg}$. The paraesthesia resolved over 72 hours.

\section{DISCUSSION}

In each case, the lesions fulfilled the radiologic criteria proposed for CMBs: they were rounded, homogeneous, small areas of low signal seen well on GRE T2*-weighted imaging but not other sequences, and were more than half surrounded by brain parenchyma. The lesions were not suggestive of mimics (e.g., calcium or iron deposition, flow voids from pial blood vessels, or partial volume artifact). ${ }^{6}$ There were no associated changes on other MRI sequences in the same regions (figures e- 1 and e-3) and the lesions lacked the characteristic heterogeneous appearance of a cavernous malformation.

A limitation of these 2 cases is that we do not have MRI scans shortly preceding their clinical presentation to confirm that the $\mathrm{CMB}$ is acutely responsible for their clinical syndrome. However, in each case, the $\mathrm{CMB}$ was found in a location typical for the clinical syndrome. In case 1 , the $\mathrm{CMB}$ was in the pons adjacent to the facial nucleus, correlating with the clinical presentation. In case 2, the $\mathrm{CMB}$ was found in the inferolateral thalamus; lesions in this region typically cause hemisensory paraesthesias in cheiro-oral or pseudoradicular distribution similar to the case reported here.

In case 1, the fainter appearance of the susceptibility artifact on follow-up MRI at 5 months is likely due to technical factors rather than resolution of the lesion as CMBs typically persist for months and years. ${ }^{6}$ Poorly controlled hypertension has been associated with the development of new $\mathrm{CMBs}^{7}$ : it is noteworthy that both patients were severely hypertensive on presentation, which may have contributed to acute CMB development.

A previous report suggested that a $\mathrm{CMB}$ could cause an acute stroke syndrome ${ }^{8}$; a patient with internuclear ophthalmoplegia was found to have a CMB in the medial lemniscus. However, in this report, the MRI was delayed for several months, with evidence of multiple lacunar infarcts, making it difficult to confirm that the $\mathrm{CMB}$ was the cause of the acute syndrome. In 
contrast, our cases were imaged within hours, allowing us to rule out acute ischemia and making any explanation other than the $\mathrm{CMBs}$ less likely.

Identifying CMBs as a cause of acute stroke syndromes using MRI may be useful, although it is difficult to be certain of the age of any CMBs detected. Whether patients with stroke syndromes attributed to CMBs should subsequently receive thrombolysis and antithrombotic treatment is unclear, but these treatments would be expected to aggravate any acute bleeding. Recent studies suggest a higher risk of intracerebral hemorrhage with antithrombotics in patients with CMBs, particularly if they are numerous and in a lobar distribution., 3

These 2 cases demonstrate the usefulness of GRE T2* MRI in the acute investigation of a TIA or stroke, and challenge the traditional view that CMBs are clinically silent. Further studies are required to determine how often $\mathrm{CMBs}$ underlie acute stroke presentations, and whether they correlate with specific syndromes.

\section{REFERENCES}

1. Atlas SW, Mark AS, Grossman RI, Gomori JM. Intracranial hemorrhage: gradient-echo MR imaging at $1.5 \mathrm{~T}$ : comparison with spin-echo imaging and clinical applications. Radiology 1988;168:803-807.

2. Jeon SB, Kang DW, Cho AH, et al. Initial microbleeds at MR imaging can predict recurrent intracerebral hemorrhage. J Neurol 2007;254:508-512.

3. Gregoire SM, Jager HR, Yousry TA, Kallis C, Brown MM, Werring DJ. Brain microbleeds as a potential risk factor for antiplatelet-related intracerebral haemorrhage: hospital-based, case-control study. J Neurol Neurosurg Psychiatry 2010;81:679-684.

4. Yakushiji Y, Nishiyama M, Yakushiji S, et al. Brain microbleeds and global cognitive function in adults without neurological disorder. Stroke 2008;39:3323-3328.

5. Greenberg SM, Vernooij MW, Cordonnier C, et al, Microbleed Study Group. Cerebral microbleeds: a guide to detection and interpretation. Lancet Neurol 2009;8:165-174.

6. Gregoire SM, Chaudhary UJ, Brown MM, et al. The microbleed anatomical rating scale (MARS): reliability of a tool to map brain microbleeds. Neurology 2009;73:1759-1766.

7. Gregoire SM, Brown MM, Kallis C, Jäger HR, Yousry TA, Werring DJ. MRI detection of new microbleeds in patients with ischemic stroke: five-year cohort follow-up study. Stroke 2010;41:184-186.

8. Watanabe A, Kobashi T. Lateral gaze disturbance due to cerebral microbleed in the medial lemniscus in the mid-pontine region: a case report. Neuroradiology 2005;47:908-911.

9. Lovelock CE, Cordonnier C, Naka H, et al. Antithrombotic drug use, cerebral microbleeds, and intracerebral hemorrhage: a systematic review of published and unpublished studies. Stroke 2010;41:12221228 .

\section{DISCLOSURES}

Dr. Teo has served as a consultant for and holds stock in GlaxoSmithKline and receives publishing royalties for Rapid Medicine, 2nd ed. (Wiley-Blackwell, 2011) and Rapid Surgery, 2nd ed. (WileyBlackwell, 2011) and 2 iPhone ${ }^{\circledR}$ apps. Dr. Ramadan reports no disclosures. Dr. Gregoire receives research support from The Stroke Association, UK. Dr. Mufti and Dr. Lipman report no disclosures. Dr. Jäger has received publishing royalties for Grainger and Allison Diagnostic Radiology: A Textbook of Medical Imaging (Churchill Livingstone, 2001). Dr. Losseff reports no disclosures. Dr. Werring receives research support from UK Department of Health and The Stroke Association, UK. 


\section{Neurology ${ }^{\circ}$ Clinical Practice}

Can cerebral microbleeds cause an acute stroke syndrome?

James T.H. Teo, Hawraman Ramadan, Simone M. Gregoire, et al.

Neurol Clin Pract 2011;1;75-77

DOI 10.1212/CPJ.0b013e31823c883d

This information is current as of December 1, 2011

\begin{tabular}{|c|c|}
\hline $\begin{array}{l}\text { Updated Information \& } \\
\text { Services }\end{array}$ & $\begin{array}{l}\text { including high resolution figures, can be found at: } \\
\text { http://cp.neurology.org/content/1/1/75.full.html }\end{array}$ \\
\hline Supplementary Material & $\begin{array}{l}\text { Supplementary material can be found at: } \\
\text { http://cp.neurology.org/content/suppl/2011/12/09/1.1.75.DC1 }\end{array}$ \\
\hline References & $\begin{array}{l}\text { This article cites } 9 \text { articles, } 5 \text { of which you can access for free at: } \\
\text { http://cp.neurology.org/content/1/1/75.full.html\#\#ref-list-1 }\end{array}$ \\
\hline Citations & $\begin{array}{l}\text { This article has been cited by } 1 \text { HighWire-hosted articles: } \\
\text { http://cp.neurology.org/content/1/1/75.full.html\#\#otherarticles }\end{array}$ \\
\hline Subspecialty Collections & $\begin{array}{l}\text { This article, along with others on similar topics, appears in the } \\
\text { following collection(s): } \\
\text { All Cerebrovascular disease/Stroke } \\
\text { http://cp.neurology.org//cgi/collection/all_cerebrovascular_disease_stro } \\
\text { ke } \\
\text { Intracerebral hemorrhage } \\
\text { http://cp.neurology.org//cgi/collection/intracerebral_hemorrhage }\end{array}$ \\
\hline Permissions \& Licensing & $\begin{array}{l}\text { Information about reproducing this article in parts (figures,tables) or in } \\
\text { its entirety can be found online at: } \\
\text { http://cp.neurology.org/misc/about.xhtml\#permissions }\end{array}$ \\
\hline Reprints & $\begin{array}{l}\text { Information about ordering reprints can be found online: } \\
\text { http://cp.neurology.org/misc/addir.xhtml\#reprintsus }\end{array}$ \\
\hline
\end{tabular}

Neurol Clin Pract is an official journal of the American Academy of Neurology. Published continuously since 2011, it is now a bimonthly with 6 issues per year. Copyright Copyright (C) 2011 by AAN Enterprises, Inc.. All rights reserved. Print ISSN: 2163-0402. Online ISSN: 2163-0933.

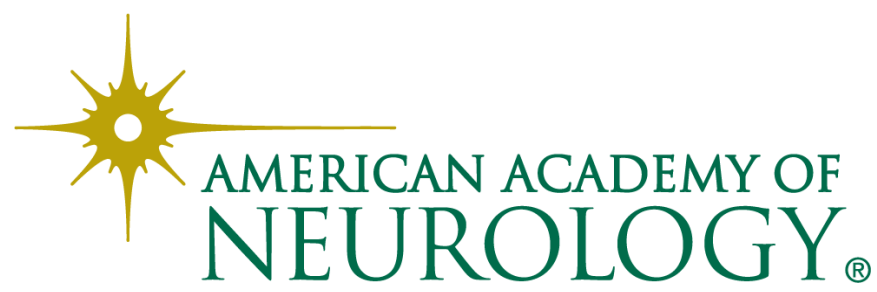

